\title{
PEDAGOGICAL PRACTICES ADOPTED BY TEACHERS WHEN TEACHING LEARNERS TAKING ENGLISH AS FIRST ADDITIONAL LANGUAGE IN LIFE SCIENCES CLASSROOMS
}

\author{
Portia Seloma, \& Sam Ramaila \\ Department of Science and Technology Education, University of Johannesburg (South Africa)
}

\begin{abstract}
This study examined pedagogical practices adopted by teachers when teaching learners taking English as First Additional Language in Life Sciences classrooms. The inquiry adopted a generic qualitative design located within the interpretivist paradigm and involved purposively selected Life Sciences teachers and grade 10 learners from South African township schools as participants. Qualitative data was collected through semi-structured interviews and classroom observations. The empirical investigation is underpinned by the Cognitive Academic Language Proficiency (CALP) as the underlying theoretical framework. The study uncovered a myriad of instructional challenges facing Life Sciences teachers and learners associated with the use of English as a medium of instruction while it is taken as a First Additional Language by the learners. In particular, the terminology used in Life Sciences as a key knowledge domain posed fundamental instructional challenges in relation to meaningful development of enhanced learners' conceptual understanding of scientific phenomena. Theoretical implications for meaningful science teaching and learning are discussed.
\end{abstract}

Keywords: Pedagogical practices, first additional language, life sciences.

\section{Introduction}

Language diversity renders classroom environment a complex and dynamic terrain for both teachers and learners. The complex and dynamic nature of classroom environment requires teachers to adopt nuanced and innovative pedagogic approaches that are responsive to the challenges posed by language diversity. Language has been identified as one of the causes of learners' poor performance in science within the South African context (Cleghorn \& Rollnick, 2002; Mji \& Makgato, 2006). Both teachers and learners bring their own diverse languages to the classroom as South Africa is a multilingual country. This study is inspired by the desire to understand how teachers teach Life Sciences content in a manner that is responsive to the language diversity of both teachers and learners. English is a medium of instruction in South African schools through which learners are expected to develop a firm grasp of scientific concepts. Yet, English is taken as First Additional Language by a substantial number of learners at South African township schools.

\section{Background}

The teaching of Life Sciences as a key knowledge domain poses enormous challenges to both teachers and learners. Learners who are taught in English as their mother tongue have an accumulated advantage in Life Science classrooms over those who are English second language speakers (Oyoo, 2014). There are various teaching strategies that can be employed by English second language teachers in Life Sciences classrooms such as the use of investigations and practical work, analogies, code switching and classroom communication (Ferreira, 2011). Wellington and Osborne (2001) point out that science has its own peculiar language and hence every science lesson is a language lesson especially in a context where the language of instruction is different from the learner's home language. The problem is exacerbated by the fact that science language is both technical and non-technical by its very nature. Technical terms are specific scientific words and non-technical terms refer to non-scientific words used in everyday life (Oyoo, 2015). Learners' acquisition and understanding of scientific concepts is often compromised by the language of instruction being different from their home language (Lee, 2001). Smith-Walters et al. (2016) identified three challenges of associated with language in science learning, namely: specialised vocabulary, the speed at which new terms are introduced in science and the 
difficulties learners face as they learn the language of science. Teachers face the key imperative to understand the language of science and how they can encourage science language acquisition within their learners (Smith-Walters, Mangione \& Bass, 2016). It is against this background that the study examined pedagogical practices adopted by teachers when teaching learners taking English as First Additional Language in Life Sciences classrooms. The empirical investigation was guided by the following research question:

What pedagogical practices are adopted by teachers when teaching learners taking English as First Additional Language in Life Sciences classrooms?

\section{Theoretical framework}

The study is underpinned by the Cognitive Academic Language Proficiency (CALP) as the underlying theoretical framework. CALP refers to the ability to manage language necessary for cognitively challenging tasks and is required for accelerated cognitive and academic growth (Laija-Rodriquez, Ochoa \& Paker, 2006). CALP is invoked as a theoretical lens to provide insightful elucidation into the nature of pedagogical practices adopted by teachers when teaching learners taking English as First Additional Language in Life Sciences classrooms.

\section{Purpose of the study}

The study examined pedagogical practices adopted by teachers when teaching learners taking English as First Additional Language in Life Sciences classrooms. The empirical investigation was underpinned by the following objectives.

- To identify pedagogical practices adopted by teachers when teaching learners taking English as First Additional Language in Life Sciences classrooms.

- To identify language barriers that impede meaningful delivery of instruction in Life Sciences classrooms.

\section{Research design and methodology}

The inquiry adopted a generic qualitative design located within the interpretivist paradigm and involved purposively selected Life Sciences teachers and grade 10 learners from South African township schools. Qualitative data was collected through semi-structured interviews and classroom observations.

\section{Research findings}

The study involved Life Sciences teachers and learners at South African township schools as participants. The demographic profile of the participants is provided in Table 1 below.

Table 1. Demographic profile of the participants.

\begin{tabular}{|l|l|c|c|c|c|l|}
\hline & Gender & $\begin{array}{c}\text { Teaching } \\
\text { experience }\end{array}$ & Grade & $\begin{array}{c}\text { Number of } \\
\text { learners }\end{array}$ & $\begin{array}{c}\text { Teacher's native } \\
\text { language }\end{array}$ & $\begin{array}{c}\text { Learners' native } \\
\text { languages }\end{array}$ \\
\hline Teacher A & Female & 3 years & 10 & 30 & IsiZulu & IsiZulu, Sepedi, Sotho \\
\hline Teacher B & Female & 5 years & 10 & 20 & IsiXhosa & Zulu, Sotho \\
\hline Teacher C & Female & 7 years & 10 & 25 & IsiZulu & Zulu, Sotho \\
\hline
\end{tabular}

Research findings were clustered according to the key themes that emerged during data analysis, namely: instructional challenges and pedagogical strategies.

\section{Theme 1: Instructional challenges}

The teachers encountered a myriad of instructional challenges when teaching learners taking English as First Additional Language in Life Sciences classrooms as reflected in the following excerpt.

The challenge that I find is that I constantly have to use second language to explain some of the concepts then I always have to translate some of the words because learners do not have a full understanding of some words, so I have to teach them language first and then teach concepts which is a bit more difficult and it takes more time than it normally should.

Language diversity appeared to pose enormous instructional challenges for the teachers when implementing code switching as a pedagogical strategy as encapsulated in the following excerpt. 
The other challenge is that me and my learners do not speak the same home language, I am Zulu, teaching kids who are Pedi's and Sotho's and Xhosa's, and these languages I am not that much good at, yet I try to speak them. Although sometimes it is difficult since I do not always know some words in their home languages which I might happen to know in my own home language, which is IsiZulu.

Other instructional challenges were related to the nature of science language used in Life Sciences as a key knowledge domain as demonstrated by the following excerpt.

Science has its own terminology. This terminology is not easy for learners to grasp let alone to pronounce some words, and this includes myself. To deal with the challenges of science language firstly is to recognise that there are some science words which are easily explainable to learners such as plants and animals since they can also be found in their homes and they can easily visualise them when they are mentioned. For example, if I say to learners, today we are going to learn about plants and animals, their minds form ideas of plants and animals they know, therefore, I use analogies using real life examples. Nonetheless, words like the xylem, phloem and epidermis, are new to them, to their minds. In this case, I use pictures to show how the plant tissue appear and ensure that I constantly assess them. I have sometimes noticed that it is not necessarily that my kids do not understand the subject life sciences, but it is its language, that is, its difficulty. So, my kids are struggling to grasp the English in the life science and also getting the science of the words that we use because life science is a very technical subject with its own language and it is little use bit far from the normal English that we use, that they are used to.

\section{Theme 2: Pedagogical strategies}

The teachers adopted various pedagogical strategies in an attempt to navigate fundamental challenges associated with the provision of instruction to learners taking English as First Additional Language in Life Sciences classrooms. Table 2 below depicts pedagogical strategies adopted by the teachers.

Table 2. Pedagogical strategies adopted by the teachers.

\begin{tabular}{|c|}
\hline Code switching \\
Use of pictures \\
Use of analogies \\
Use of video clips \\
\hline
\end{tabular}

\section{Discussion}

Teaching learners taking English as First Additional Language in Life Sciences classrooms appeared to be an extremely difficult and complex undertaking for teachers. Language proficiency plays a pivotal role in demystifying the nature of scientific knowledge. The teachers' Cognitive Academic Language Proficiency (CALP) affects the instructional process as teachers' English proficiency influences learners' acquisition of the concepts to be learned (Nel \& Muller, 2010). The vocabulary load presented in most science textbooks continues to be high and may contribute to misconceptions, lack of understanding and avoidance of the subject (Pearson, Hiebert \& Kamil, 2007). The teachers adopted various pedagogical strategies when navigating fundamental challenges associated with the provision of instruction to learners taking English as First Additional Language in Life Sciences classrooms within the context of this study. However, meaningful implementation of adopted pedagogical strategies required enhanced professional competence on the part of teachers. Barriers that served to impede meaningful delivery of instruction in Life Sciences classrooms included language diversity, terminology used in Life Sciences as a key knowledge domain and general lack of essential resources. There is a critical need for teachers as key agents of educational change to fully embrace contemporary teaching approaches such as inquiry-based learning to demystify the nature of scientific knowledge. As an innovative pedagogic approach, inquiry-based learning can serve to augment pedagogical strategies such as code switching and the use of analogies to ensure immense pedagogical benefits for the learners. 


\section{Conclusion}

Teaching learners taking English as First Additional Language in Life Sciences classrooms appears to be a daunting task for teachers. Teacher professional training ought to make provision for meaningful development of language proficiency with a view to build professional capacity required to demystify the nature of scientific knowledge.

\section{References}

Cleghorn, A., \& Rollnick, M. (2002). The role of English in individual and societal development: A view from African classrooms. Tesol Quarterly, 36(3), 347-372.

Ferreira, J. G. (2011). Teaching life sciences to English second language learners: What do teachers do? South African Journal of Education, 31(1), 102-113.

Laija-Rodriguez, W., Ochoa, S.H., \& Paker, R. (2006). The Cross-linguistic role of Cognitive Academic Language Proficiency on reading growth in Spanish and English. Bilingual Research Journal, 30(1), 87-106.

Lee, O. (2001). Culture and language in science education: What do we know and what do we need to know? Journal of Research in Science Teaching, 38(5), 499-501.

Mji, A., \& Makgatho, M. (2006). Factors associated with high school learners' performance: A spotlight of Mathematics and Physical Sciences. South African Journal of Education, 26, 253-266.

Nel, N., \& Muller, H. (2010). The impact of teachers limited English proficiency on the English second language in South Africa. South African Journal of Education, 30, 635-650.

Oyoo, S.O. (2014). Language of Instruction and Science Learning in African Science Classrooms, In Daniel O. Orwenjo, Martin C. Njeroge, Ruth W. Ndung'u and Phyllis W. Mwangi (Eds.); Multilingualism and Education in Africa: The State of the state of the Art, (pp. 24-49). Cambridge: Cambridge Scholars Publishing.

Oyoo, S.O. (2015). Why language is so important in science teaching. World Economic forum.

Pearson, Hiebert, E.H., \& Kamil, M.L. (2007). Theory and research into practice: A vocabulary assessment: What we know and what we need to learn. Reading Research Quarterly, 42(2). 282-296.

Smith-Walters, C., Mangione, A.K., \& Bass, S.A. (2016). Science language special issue: Challenges in preparing preservice teachers for teaching science as a second language. Electronic Journal of Science Education, 20(3), 60-71.

Wellington, J., \& Osborne, J. (2001). Language and literacy in science education. Buckingham: Open University Press. 